\title{
IMPACT OF INTERNET CHANNEL ON THE SERVICE CANNIBALIZATION PERCEPTION AND THE ROLE OF RELATIVE CAPITAL ${ }^{1}$
}

\author{
Ayşegül ACAR ${ }^{2}$ \\ Samet GÖKKAYA ${ }^{3}$ \\ Cenk Murat KOÇOĞLU ${ }^{4}$
}

\author{
Received Date (Başvuru Tarihi): 01/11/2018 \\ Accepted Date (Kabul Tarihi): 15/11/2018 \\ Published Date (Yayın Tarihi): 30/11/2018
}

\section{ABSTRACT}

The purpose of this study is to examine the perceptions of sales agent representatives' service cannibalization and its possible outcomes (effort, job satisfaction, job performance and job alienation) resulting from ICT especially internet adoption as an alternative distributional channel in tourism industry. In addition, causal relationships between these possible outcomes have been tried to be revealed. According to field studies carried out in 2016 with 387 group A sales representatives working in travel agencies that are members of TÜRSAB located in the European side of Istanbul, it was determined that the relational capital levels of the sales representatives were relatively low while the service cannibalization perceptions reached a moderate result. A regression analysis was conducted to test hypotheses established in the theoretical and framework of the research. Service cannibalization has been identified as a predictor of effort, job satisfaction, job performance and job alienation. Another result reached through the study is that the level of relational capital as a partial mediator between sales agent's service cannibalization perception and its outcomes. At the end of the work, various suggestions were made to Travel Agencies.

Keywords: Service Cannibalization Perception, Relational Capital, Information and Communication Technology (ICT), Tourism Distribution Channels

JEL Codes: M31, Z32

\section{INTERNET KANALININ SERVIS KANIBALIZASYON ALGISI ÜZERINDEKI ETKISİ VE İLIŞKISEL SERMAYENIN ARACI ROLÜ}

\section{$\ddot{O} \mathbf{Z}$}

Çalışmanın amacı; BİT' lerin özellikle internetin turizm endüstrisine alternatif dă̆ıtım kanalı olarak dâhil edilmesinin seyahat acentesi satış temsilcileri üzerinde yarattı̆̆ servis kanibalizasyon algısının ve olası sonuçlarının (çaba, iş memnuniyeti, iş performansı ve işten uzaklaşma) tespit edilmesidir. Ayrıca bu olası sonuçlar arasında ki nedensel ilişkiler ortaya konulmaya çalışılmıştır. Araştırma kapsamında İstanbul ili Avrupa yakasında bulunan ve TÜRSAB'a üye A grubu seyahat acentelerinde çalışan 387 satış temsilcisiyle, 2016 yılında gerçekleştirilen saha çalışmalarına göre; satış temsilcilerinin servis kanibalizasyon algıları orta düzeyde bir sonuca ulaşırken, ilişkisel sermaye düzeyleri görece düşük olduğu saptanmıştır. Araştırmanın amact ve kuramsal çerçevesinde kurulan hipotezleri test etmek için regresyon analizi gerçekleştirilmiştir. Servis kanibalizasyon algısının, çaba, iş memnuniyeti, iş performansı ve işten uzaklaşma üzerinde yordayıcı bir değişken olduğu belirlenmiştir. Araştırmada ulaşılan diğer sonuç ise ilişkisel sermaye düzeyinin satış temsilcilerinin servis kanibalizasyon algısı ve sonuçları üzerinde kısmi aracı değişken olduğudur. Çalışmanın sonunda Seyahat Acentelerine çeşitli öneriler sunulmuştur.

Anahtar Kelimeler: Servis Kanibalizasyon Algısı, Illişkisel Sermaye, Bilgi iletişim Teknolojisi (BİT), Turizm Dă̆ıtım Kanallarl

JEL Kodları: M31, Z32

\footnotetext{
${ }^{1} \mathrm{Bu}$ çalışma 12-14 Eylül 2018 tarihlerinde Safranbolu'da düzenlenen "Business \& Organization Research (BOR)" Konferansı'nda bildiri olarak sunulmuştur.

${ }^{2}$ Research Assistant, Karabuk University, Tourism Faculty, aysegulacar@karabuk.edu.tr

${ }^{3}$ Research Assistant, Karabuk University, Tourism Faculty, $\underline{\text { sametgokkaya@ @arabuk.edu.tr }}$

${ }^{4}$ Assistant Prof. Dr., Karabuk University, Tourism Faculty, cmkocoglu@ karabuk.edu.tr

https://orcid.org/0000-0002-1871-4904 https://orcid.org/0000-0002-4592-8641 https://orcid.org/0000-0002-9888-6051
} 


\section{INTRODUCTION}

Distribution channels respond quickly to market dynamics as well as adapting to both industry and consumer needs. The most comprehensive change in tourism distribution channels has been made by information and communication technologies (ICT) dominating the industry (Buhalis and Law, 2008). In the multi-channel distribution system of the tourism industry, online channels have changed the role of offline channels, which are physical entities and provide face-to-face communication with customers (Berne, Garcia-Gonzalez, and Múgica, 2012). Prior to the Internet, suppliers and consumers had no choice but to use intermediaries such as travel agencies. But the widespread use of the Internet and other ICTs has caused the value chain structure to change drastically. This change has led to divergent changes that are reflected in each of the distribution channel bodies that have affected unequally in different ways, and at the same time has made a major contribution to tourism.

The competition system, called "disintermediation", which this situation reveals, allows the consumer to communicate directly with the supplier or destination via electronic means. This has led to the removal of intermediaries such as tour operators and travel agencies in the distribution channel (Bennett and Buhalis, 2003), which has led to a dangerous situation as the consumer has provided the shopping needs with online methods. Various researches show that the competition system called disintermediation, which the internet reveals, changes the buying tendency of the target customers and in this case the sales representatives working in the travel agents lead the questioning of the certainty of the future of the business (Gulati, Bristow, and Dou, 2002; Sharma and Gassenheimer, 2009). There are differences between disintermediation and the perception of service cannibalization, which are similar concepts and can produce similar results.

The cannibalization perception is reflected in the responses of travel agent sales representatives to the difficulties resulting from the expansion of distribution channels (including the Internet). Disintermediation is formed by the involvement of internet channels among the established channels and the threat of destruction of the traditional channels (Alba et al., 1997; Coughlan, Anderson, Stern, and El-Ansary, 2001; Narayandas, Caravella, and Deighton, 2002). Current research shows that perceived cannibalization has motivational, emotional and financial impacts on travel agency customer representatives (Sharmave Gassenheimer, 2009). Perceived cannibalization has widened the perceptions of the contraction in the industry due to the intrusive influence of the internet and at the same time the changes it has shown also affect the sales agent's sales agent, market shares and roles and fall due to online channels. The increase in sales through online channels, the role of agent sales representatives and the decline in sales shares are conceptualized as service cannibalization (Sharmave Gassenheimer, 2009). This means that both the decrease in sales of sales representatives and the 
presence of multiple channels that provide online service to customers are causing scepticism about the sustainability of agency representatives' business and lead to some adverse effects on sales representatives.

The concerns of agency sales representatives related to service cannibalization and job security reduce the effort they are putting into their jobs, adversely affect their performance, reduce their satisfaction from the workplace and cause them to move away from work. Even though sales representatives have an uncertain future feeling have relational capital, they will have a sense of tension in the working environment. Despite the interest on the changing circumstances of tourism distribution channels, there are a few studies in the literature referring to the perception of the cannibalization of travel agency customer representatives. Some researchers argue in their studies that travel agency customer representatives are reacting negatively to online markets in their work (Goldmanis et al., 2010). This study empirically analyses the service cannibalization perceptions and effects (effort, job satisfaction, job performance, job alienation) of travel agent sales representatives. It has also been attempted to analyse the effects of the relationship capital between the sales representative and the agency, i.e. the representative, on the service-cannibalization perception

\section{LITERATURE REVIEW}

\subsection{Distribution Channels in the Tourism Industry}

Tourism distribution is a system of intermediary services that enables the sale of services and products of channelled tourism services to the consumers from the suppliers. (Buhalis and Laws, 2001). For this reason, multi-channel distribution in tourism can be perceived as a combination of customer notification, transportation and provision of guest hospitality services and travel organizations (Pearce, 2009; Pearce and Tan, 2006). According to Hudson (2008), tourism distribution channels are direct tour operators when they serve as sales points for suppliers (airlines, hotels, etc.) and indirect sales channels when they sell through intermediary sales points such as travel agencies and online agencies. Since the rise of ICTs, the distribution channels of internet channels have changed the tourism products and services (Wang and Qualls, 2007). With the increasing use of the Internet, especially in Information Communication Technologies (ICT) in the tourism industry, a more competitive environment has formed in the sector and ICTs have become an indispensable element for the development of this sector (Berné et al., 2015). ICTs have begun to remove geographical barriers and have created a globalizing tourism market. It has created a global marketplace that offers unlimited product alternatives with low transaction fees to consumers and travel agencies and allows companies to more easily globalize their operations and reach remote customers. This means low transaction fees for suppliers and low costs for entry and exit, and for many consumers the ability to reach more travel 
with multiple channels (Berné et al., 2012). Moreover, with the impact of ICT in the tourism sector, this has triggered the emergence of complex structures and the ignoring of the traditional methods of new intermediary players entering the market has resulted in the dismissal of some players by intermediaries (Buhalis and Law, 2008). Though technological-induced structural changes provide more opportunities for consumers, it also leads to a more intense competition between channel participants (Pearce et al., 2004).

There are many published works in the literature that show how ICT changed the tourism industry and how companies and consumers can benefit from ICT use (Buhalis and Law 2008; Hjalager, 2010). Some research has focused on the impact of the use of new technologies on the performance of tourism service providers and supported the information and management processes in the tourism sector (Buhalis and Michopoulou 2013; Sigala and Chalkiti, 2014). Some studies have analysed in detail the ICT's integration process with the tourism industry and the possible benefits it could provide to travel agencies and tour operators (Roger-Monzó et al., 2015; Standing et al.,2014). Spencer et al. (2012), for example, assessed the distribution of innovation theory and technology adoption model and discovered the factors that affect the decision-making process of travel agencies' use of technology. As a result, the tourism industry has become a prioritized reference for how the ICT can change the structure of a sector, and it has become an interesting research topic. However, there are few studies of sales agents analysing their thoughts about service cannibalization in travel agencies.

\subsubsection{Service Cannibalization Perceptions of Travel Agency Sales Representatives}

Online channels allow travel agencies to strengthen existing markets and open new markets (Ansari et al., 2008; Geyskens et al., 2002). However, the integration of multi-channel distribution (online and offline channels) has great danger for the tourism industry. Internet sites can have detrimental effects on travel agencies by offering features that are more attractive to consumers (airplane, hotel, car rental, reservations, etc.), and they can also cause sales to slip from large travel agencies to internet sites (Avery et al., 2012). The Internet offers tremendous amount of information, along with time savings on customization features and products that can be done to consumers, and it reduces the need for human communication in retail locations to a great extent. In this case, mixed requests received via online and offline channels cause retail organizations to be cannibalized by online channels (Cai et al.,2009; Kollmann et al.,2012). The most significant impact for retail sales agents is the psychological impact of service cannibalization on sales representatives (Geyskens et al., 2002). Sharma and Gassenheimer (2009) refer to service cannibalization as a subjective threat to the diversity of distribution channels the introduction of an online channel to a company or industry distribution system. 
Travel agencies that serve as retailers in the tourism industry can claim online channels as well as their traditional sales methods. Agencies who wish to sell on these channels will use the online travel agency and internet sites to use the person or system that is online. This creates a perception that the role of the sales agent working at the travel agency is threatened by entering competition with the emerging new distribution channel traditional travel agency, which reveals the perception of service cannibalization in sales representatives.

This problem is especially important in today's conditions to influence many situations. Because the widespread use of the Internet affects the reliability of traditional professions and leads to a change in the responsibilities of employees in certain roles. In this case, as in the tourism sector, it affects the motivation of sales representatives negatively in many sectors. Sales representatives, who are once the only point of contact with the consumer, fear that the cannibalization perception in the industry will lead to contradictions and distress and may take their place by showing themselves as fashionable in the industry where the Internet will prove both its own roles and sales (Porter, 2001).

\section{OBJECTIVES AND HYPOTHESES OF RESEARCH}

The purpose of the research is to determine the perception of the potential of cannibalization and its possible consequences on ICT sales representatives, especially when the internet is an alternative distribution channel in the tourism industry. The aim of the research is to determine the perception of the cannibalization and its possible consequences, especially on the internet, in the tourism industry, and on the travel agent sales representatives created by the alternative distribution channel of ICTs. Another aim of the study is to find out how the level of relational capital that employee has, that is the confidence, mutual understanding and cohesiveness of the employee with the institutions and employers they work with, is influenced by the service cannibalization perception and its possible consequences (effort, job satisfaction, job performance and job alienation-being mentally distanced from work). The relations established in this context are as follows.

\subsection{Service Cannibalization Perception of Sales Representatives and Effort}

Effort is the power, energy and mobility used to achieve a job (Brown and Peterson, 1994) and is categorized in the motivation expectation theory. According to this theory, the motivation of the sales representative is directly proportional to the expectation of the effort that the representative will spend to reach a goal. In parallel with what Vroom (1964) says and the works Hall and Lawler (1970), employees strive to be proportional to the expected results. For example, anticipation of competition due to the use of the internet can decrease performance expectations, which will break the motivation of sales representatives and increase expectations for negative outcomes. This view is like the study of Rousseau (1989). According to this study, lack of commitment among sales agents leads sales 
representatives and their efforts to move away from the agency's goals. Thus, the perception that the internet will cannibalize sales prevents sales representatives from exhibiting a high level of effort and eventually leads to a fall in efforts (Frazier, 1999; Sharma et al., 2010). In other words, competition in tourism industry due to online channels makes it difficult for sales representatives to fulfil their role in the business as it makes it difficult to meet the expectations of sales representatives. Thus; H1: There is a relationship between the salesperson's sense of service cannibalization and the effort they are making.

\subsection{Service Cannibalization Perception of Sales Representatives and Job Satisfaction}

Job satisfaction is a psychological condition that arises from the evaluation of one's job, his or her work, or other experience in this context (Locke, 1976). Job satisfaction is, in fact, a positive outcome of a positive evaluation of the work experience of the worker (Brown and Peterson, 1993; Homburg and Stock, 2004; Locke, 1979). In addition, Bowling, Hendricks, and Wagner (2008) argue that working conditions and conditions affect employee behaviour. While some definitions focus on certain aspects of work (Hunt et al.,1985), other definitions show work satisfaction as a general satisfaction state, including feelings of business (Boonzaier, et al., 2001). Changes such as the introduction of online channels into the industry create an undesirable competitive environment and cause job insecurity (Davy, et al.1997). Hinrichs (1968), which defines job satisfaction as an emotional response to things that are perceived as fair and logical, is the predominant factor in assessing the employee's overall business. As is evident from the theory of uncertainty reduction and the work of Ghosh (1998), the internet option will often lead to a high level of uncertainty for sales agent representatives and an uncomfortable competition. Previous studies have also shown that the feeling of uncertain working conditions will affect employees' job satisfaction negatively (Ashford et al.,1989; Davy et al.,1997; Rosenblatt and Ruvio, 1996. Thus; H2: There is a relationship between sales representative's service cannibalization and job satisfaction.

\subsection{Service Cannibalization Perception of Sales Representatives and Work Performance}

In recent times, researchers have defined performance as a comparison of employees' achievements with their sales targets to the production of new sales receipts and their earnings compared to other employees in the organization that they work with. (Amyx et al., 2008; Dwyer et al., 2000; Sallee and Flaherty, 2003). In tourism industry, business performance in travel agencies is defined as comparing their sales commission income, sales targets, sales income and average performances to other sales representatives in similar situations. Industrial organization psychologists have stated that employees are not confident about their performances for many reasons (Greenhalgh and Rosenblatt, 1984; Walsh, 1988). Especially one of the reasons related to the subject is that there 
are situations that are not liked and risky in working environment and working conditions (Staw et al., 1981). D'Aveni (1989) revealed in his work that employees' performance falls in risky environments. Increasing the choice of communication and distribution channels for consumers can lower the confidence of the sales agency representatives against their work performance because the perception of cannibalization raises the risk and makes the business unsafe to exist for the future (Porter, 2001). Previous studies indicate that this unreliable insecurity disturbs employees in their working environment and their daily lives and affects their performance negatively (Dekker and Schaufeli, 1995; Hellgren et al.,1999). Thus; H3: There is a relationship between the sales representative's service cannibalization perception and work performance.

\subsection{Service Cannibalization Perception of Sales Representatives and Job Alienation}

Job Alienation is the attitude that an employee expresses a lack of interest in his work (Hirschfeld et al.,2000). It can be described as employee's less interest in the job and the tendency to work more reluctantly (Moch, 1980). More specifically, the concept of job alienation is a psychological change that results in an imbalance between the effort made and the results achieved. Innovative changes in the tourism distribution system have led to changes in the development of the operator, new skills and changes inherent in the nature of the business and put more pressure on the employees (Di Pietro and Pizam, 2008), and in addition, they reveal the feeling of alienation (Cheung, 2005). In the work of Sharma and Gassenheimer (2009) and in other studies, it has been found that cannibalization expected by the sales representatives of the presence of the internet option increases the uncertainty in the workplace (Berger, 1979, 1986; Planalp and Honeycutt, 1985; Shannon and Weaver, 1949). This increasing uncertainty about the relative role or duty in the agency can result in employees being psychologically disconnected from their work (Allen and LaFollette, 1977). In addition, previous studies also indicate that job insecurity has an impact on attitudes towards work (Hellgren et al., 1999). The presence of the Internet option among distribution channels makes this option insecure for sales representatives who think they will reduce their sales potential (Porter, 2001). The view that employees tend to be more likely to be alienated from work in an environment that has the potential to cause job insecurity is also supported in the literature (Blauner, 1964; Shepard, 1971). The emergence of an online distribution channel of service cannibalization perception results in psychological distancing of sales representatives from their works, resulting in job alienation is supported by studies (Shannon and Weaver, 1949). Thus; H4: There is a relationship between the sales representative's service cannibalization perception and Job Alienation. 


\subsection{Intermediary Role of Relational Capital}

Relational outcomes are mostly explained through relational capital. The concept of relational capital advocates the development of abstract and tangible assets possessed in relation to each other (Kale et al.,2000; Morgan and Hunt, 1994; Seabright et al., 1992). The level of the relational capital between the sales representatives and the agent is seen as the strength of the agency's relationship with the employees, even though the agency uses alternative delivery channels to increase sales revenues, such as the internet (Granovetter, 1973; Mackenzie, 1996; Thibaut and Kelley, 1959). From the works of Kale, Singh and Perlmutter (2000), Mackenzie (1996), Morgan and Hunt (1994) and Zaheer, McEvily and Perrone (1998), it can be said that relational capital includes mutual trust and mutual understanding, harmony and cooperation in various levels between agency and sales representative.

The fact that the sales representative has high-level relational capital causes it to act in a way that will benefit both sides (Akerlof and Yellen, 1990; Gouldner, 1960). Otherwise, the lack of relational capital causes sales representatives to question the intent of the agency, which in this case leads to uncertainty in terms of sales representatives and put the relationship into a risk (Rogers, 1975). Thus, relational capital should play a regulatory role by making the perceptions of sales representatives parallel to the agency's view. As a result, sales representatives with high relational capital tend to favour the agent's new sales channels and think that adding this new route will not adversely affect the results of their own work efforts. Supporting this, Kogut (1991) argued that high-level relational capital would be able to confront the difficulties that would arise due to the perceived uncertainty of both sides. Even relational capital has the duty of balancing the negative perceptions that the internet option will create for its sales agents. Thus, relational capital must be a factor that regulates the relationship between sales representatives' effects on the service cannibalization perception. Hypotheses established in this context;

$H_{5 a}:$ There is an intermediary effect of relational capital between service cannibalization perception and employee effort.

$H_{5 b}$ : There is an intermediary effect of relational capital between service cannibalization perception and employee job satisfaction.

$H_{5 c}$ : There is an intermediary effect of relational capital between service cannibalization perception and employees' work performance.

$H_{5 d:}$ There is an intermediary effect of relational capital between service cannibalization perception and employees' job alienation. 


\section{RESEARCH METHOD}

Quantitative research method was used to test hypotheses established within the scope of this study and survey technique was used as data collection tool. For all scales formed of 5-point Likert scales, responses were rated from 1 (strongly disagree) to 5 (strongly agree). The 4-point service cannibalization perception scale of sales representatives developed by Sharma and Gassenheimer (2009) was used to determine the service cannibalization perception of the employees. The effort was assessed by using the 4-point Effort scale developed by Brown and Peterson (1994) and for employees' job satisfaction was assessed by using the 3-point job satisfaction scale developed by Netemeyer, Johnston and Burton (1990). Work performance was assessed by 5-point scale developed by Dwyer, Hill, and Martin (2000). Miller, 1967 Agarwal, (1993) developed a 5-item scale for assessing the alienation levels of employees. Finally, Kale, Singh, and Perlmutter (2000) developed a 5-point relational capital scale that serves as an intermediary role in the study. In the present study, relational capital refers to the relationship between the agency and sales representatives. The data were gathered with a field study carried out on sales representatives working in the region by reaching 152 group A travel agencies out of a total of 3265 travel agencies that are members of TÜRSAB in Istanbul in 2016.

The reason for choosing group A travel agencies as a research area is that group A travel agencies have the authority to organize overseas tours and to be the distributor of foreign tour operators in the country. For them, the use of internet distribution channel is a necessary condition for global market opening. In addition, according to other groups, the group A travel agencies to have more professional work in management and management policies and to have the head offices mostly in Istanbul have been an important factor. A total of 387 valid surveys were obtained and frequency, reliability and factor analyses were performed by loading them into the statistical package program. In addition, a correlation analysis of the expressions related to the scales was performed and the relationship levels were tested. Subsequently, regression analysis was performed to test the research hypotheses. Baron and Kenny (1986) state that some conditions must be met for intermediary tests to be carried out. The three independent variables of these conditions are the effects of the agent on the dependent variable and the effect of the agent on the dependent variable. In addition, when the tool is included in the variable model, it is expected that the effect of the argument on the dependent variable will be reduced or terminated, so that a meaningful intermediary effect can be mentioned. Hence, hypothesis results were evaluated by determining whether these conditions were met by simple regression analyses used in this research. 
It is very important that the expressions in the adaptation of the foreign language scale are appropriate to the language and culture to be adapted. In this context, after the necessary permissions were obtained from the scale owners, the scales were adapted to Turkish by two academicians who mastered the English language. After this adaptation, a different academician conducted the translation into English. After the linguistic validity was obtained after the studies done, the validity and reliability analysis of the scale was examined. Explicit Factor Analysis (EFA) was performed first in order to determine the validity of the structure of the scale.

Table 1. Factor Analysis Results Related to Scales

\begin{tabular}{|c|c|c|}
\hline Scale Names & $\begin{array}{l}\text { Factor } \\
\text { Load }\end{array}$ & $\begin{array}{l}\text { Cronbach } \\
\text { Alpha }\end{array}$ \\
\hline \multicolumn{3}{|l|}{ Scale-1: Sales Agent Perceived Service Cannibalization } \\
\hline I am losing market share to internet tourist service sales & ,631 & \\
\hline $\begin{array}{l}\text { Large numbers of my present and future customers may instead choose tos hop } \\
\text { for tourists service online. }\end{array}$ &, 569 & $\mathbf{0 , 8 0}$ \\
\hline $\begin{array}{l}\text { I think I am losing a large number of customers to competing ICT and internet } \\
\text { channels }\end{array}$ & 637 & \\
\hline $\begin{array}{l}\text { I think I could sell more tourist services if my and other company did not sell } \\
\text { insurance online. }\end{array}$ & 648 & \\
\hline \multicolumn{3}{|l|}{ Scale-2: Effort } \\
\hline Compared to my colleagues, I put in more effort serving my clients. &, 704 & \\
\hline Compared to my colleagues, I put in a lot of effort in the sales tasks. & ,739 & 0,84 \\
\hline Compared to my colleagues, I put in more hours in my job. & ,777 & \\
\hline \multicolumn{3}{|l|}{ Scale-3: Job Satisfaction } \\
\hline In general, I am pretty happy with my dealings with my company. &, 728 & \\
\hline I really like working for my company. & ,719 & ,799 \\
\hline I am satisfied with the products and services I get from my company. &, 733 & \\
\hline \multicolumn{3}{|l|}{ Scale-4: Job Performance } \\
\hline Compared to my colleagues, I believe I earn more commission. & 499 & \\
\hline I always exceed the sales objectives and targets set for me. & ,736 & \\
\hline Frankly, I don't perform as well as other sales agents in this job (reverse coded). & 670 & ,779 \\
\hline Compared to my colleagues, I generate more sales revenue. & ,664 & \\
\hline Overall, my performance is superior to a typical sales agent in my firm. &, 350 & \\
\hline
\end{tabular}


Scale-5: Rational Capital

There is close personal interaction between me and my company.

The relationship between me and my company is characterized by mutual respect.

The relationship between me and my company is characterized by trust.

The relationship between me and my company is characterized by cooperation. ,682

\section{Scale-6: Job Alienation}

Selling tourist products and services for my agent provides me an opportunity to excel

, 480

I really do not feel a sense of pride or accomplishment as a result of selling touristic products and services for my agent

I am proud to have done well in selling tourist products and services for my company

Selling touristic product and services for my agent is a rewarding experience

Total Variance Explained:

69,781

Table 1 shows the results of the Explicit Factor Analysis and the reliability analysis of the overall scale for the relevant scales. Explanatory factor analysis was performed to determine the dimensions and scale reliability of the variables used in the study and Cronbach's alpha coefficients were calculated. The factor analysis rotation method is preferred as Varimax. The results are shown in Table 1. As a result of the factor analysis, the questions were gathered as expected under predicted scales. Moreover, all scale questions explain about $70 \%$ of the total variance. The Cronbach's Alpha Coefficients for the scales used were above the lower limit of 0.70 (Nunnally and Bernstein, 1994). From this point of view, it can be said that the scales are very reliable.

Confirmatory Factor Analysis (CFA) was used to test the appropriateness of the factors identified by the AFA in the second phase of the study to the factor structures determined by the hypothesis. Exploratory factor analysis is performed in order to understand whether the resulting 6factor structure compares favourably with the sample data, CFA was performed using the AMOS 16.0 packet program and the corresponding path diagram is given in Figure 1. In fact, this factor corresponds to the factor loadings in classical factor analysis. In a sense, these arrows give information about how well each item is a representative of its implicit variable. According to the analysis path coefficients ranged from 0.47 to 0.86 and result that all of them showed acceptable adaptability. 


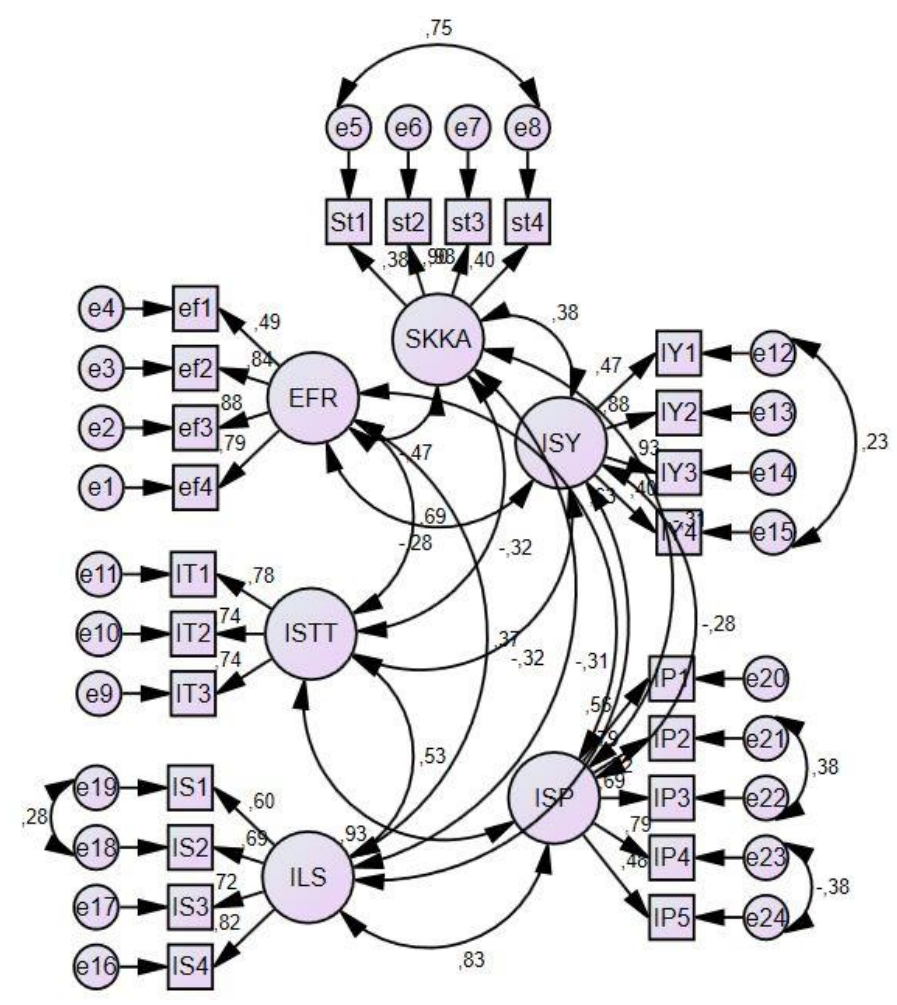

Figure 1. Scale Path Diagram and Factor Loads

Table 2. Comparison of Research Results With Compliance Goodness Criteria

\begin{tabular}{llll}
\hline $\begin{array}{l}\text { Compliance } \\
\text { Criteria }\end{array}$ & Best Compliance & Acceptable Compliance & $\begin{array}{l}\text { Compliance Criteria Obtained } \\
\text { Research Result }\end{array}$ \\
\hline$\chi 2$ & $0 \leq \mathrm{c} 2 \leq 2 \mathrm{df}$ & $2 \mathrm{df} \leq \mathrm{c} 2 \leq 3 \mathrm{df}$ & 982,470 \\
P Değeri & $0.05 \leq \mathrm{p} \leq 1$ & $0.01 \leq \mathrm{p} \leq 0.05$ &, 000 \\
$\chi 2 / \mathrm{df}$ & $0 \leq \mathrm{c} 2 / \mathrm{df} \leq 2$ & $2 \leq \mathrm{c} 2 / \mathrm{df} \leq 3$ & 4,235 \\
RMSEA & $0 \leq \mathrm{RMSEA} \leq 0.05$ & $0.05 \leq \mathrm{RMSEA} \leq 0.08$ &, 079 \\
SRMR & $0 \leq \mathrm{SRMR} \leq 0.05$ & $0.05 \leq \mathrm{SRMR} \leq 0.10$ &, 049 \\
NFI & $0.95 \leq \mathrm{NFI} \leq 1.00$ & $0.90 \leq \mathrm{NFI} \leq 0.95$ &, 891 \\
CFI & $0.97 \leq \mathrm{CFI} \leq 1.00$ & $0.95 \leq \mathrm{CFI} \leq 0.97$ &, 961 \\
GFI & $0.95 \leq \mathrm{GFI} \leq 1.00$ & $0.90 \leq \mathrm{GFI} \leq 0.95$ &, 913 \\
AGFI & $0.90 \leq \mathrm{AGFI} \leq 1.00$ & $0.85 \leq \mathrm{AGFI} \leq 0.90$ &, 851 \\
RFI & $0.90<\mathrm{RFI}<1.00$ & $0.85<\mathrm{RFI}<0.90$ &, 872 \\
\hline
\end{tabular}

Source: Schermelleh-Engel-Moosbrugger (2003)

As a result of the analysis made, values of $\chi 2=982,470(\mathrm{df}=233, \mathrm{p}<.001)$ were obtained regarding the structure of 6 scales consisting of 24 items. According to the results obtained, Chi square 
value is expected to be meaningful, but this value is very sensitive to the sample size and it can mostly come out at significant level in large sample groups. In this respect, a calculation, which is obtained by dividing the ratio of Chi square ratio obtained as an alternative to the degree of freedom, is proposed (Byrne, 1989; Kline, 1994) In the study conducted, this ratio was found to be $\left(\chi^{2} / \mathrm{df}=4.35\right)$. If the ratio is at two or below, it indicates that the model is a good model. A value of five or less indicates that the model has an acceptable fit (Şimşek, 2007). Therefore, the value obtained is an important proof that the model is an acceptable model.

In addition, Goodness of Fit Index (GFI), Adjusted Goodness of Fit Index (CFI), Comparative Fit Index (CFI), Root Mean Square Error of Approximation (RMSEA) and Standardized Root Mean Square Residual (SRMR) compliance indexes were also calculated. Although the acceptability levels of the indicated compliance indices vary according to different authors, it is generally acceptable for the GFI, AGFI and CFI to be .90 and above, an acceptable compliance fit of RMSEA .08 and SRMR below .10 (Kline, 1998; Şimşek, 2007). The analysis made in Table 2 is determined as RMSEA= 0.079; $\mathrm{SRMR}=0.049 ; \mathrm{GFI}=0.913 ; \mathrm{AGFI}=0.851 ; \mathrm{NFI}=0.891 ; \mathrm{CFI}=0.961 ; \mathrm{RFI}=0.872$. While some compliance indices were obtained, some were not achieved, but as a result, the survey was identified by the compliance markers of confirmatory factor analysis consisting of 24 items and 6 scales, and this model was found to be theoretically and statistically relevant.

After ensuring the required reliability and validity condition, the average score for expressions of each scale was calculated (The reverse questions on the scales are turned over). Each scale score ranges from 1 to 5 .

Table 3. Descriptive Statistics on Scales

\begin{tabular}{lll}
\hline & Mean & $\begin{array}{l}\text { Standard } \\
\text { Deviation }\end{array}$ \\
\hline Service Cannibalization Perception & 3,57 & 1,14 \\
Effort & 3,72 &, 79 \\
Job Satisfaction & 3,36 &, 89 \\
Jo Performance & 3,31 &, 76 \\
Job Alienation & 3,50 & 1,11 \\
Relational Capital & 2,99 &, 92 \\
\hline
\end{tabular}


The mean and standard deviation scores of the relevant scale sub-dimensions of the employees participating in the survey are shown in Table 3. According to this, the average of the service cannibalization perception of the employees is 3,57 and the relational capital average is 2,99 .

\section{RESEARCH FINDINGS}

Table 4. Frequency Distribution of Demographics Related to Sales Representatives Working in Travel Agencies

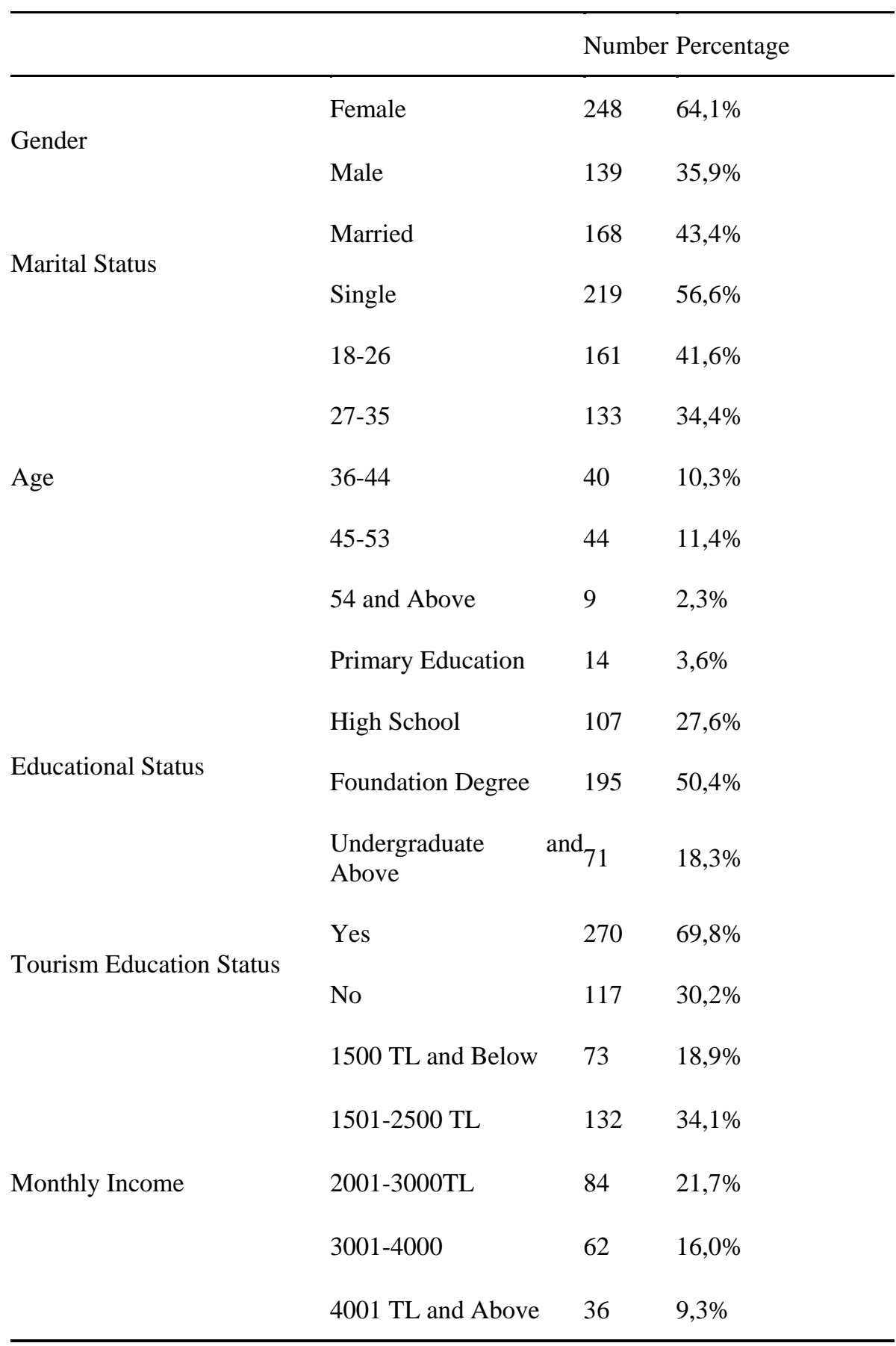


Table 4 shows the frequency distribution of the demographics of the sales representatives working in the travel agencies participating in the survey. Accordingly, $64.1 \%$ of the employees participating in the survey are women and $35.9 \%$ are male. $56.6 \%$ of the employees are single and $41.6 \%$ are between the ages of $18-26$. When the educational status of the employees is examined, it is determined that $50.4 \%$ are graduates of associate degrees, $27.6 \%$ are graduates of high schools and $18.3 \%$ are graduates of undergraduate and graduate departments. $69.8 \%$ of the people working in travel agencies stated that they have received education in tourism. $34.1 \%$ of the employees were paid between 1501-2500 TL and 21.7\% were paid between 2001-3000 TL.

Table 5. Results of Correlation Analysis

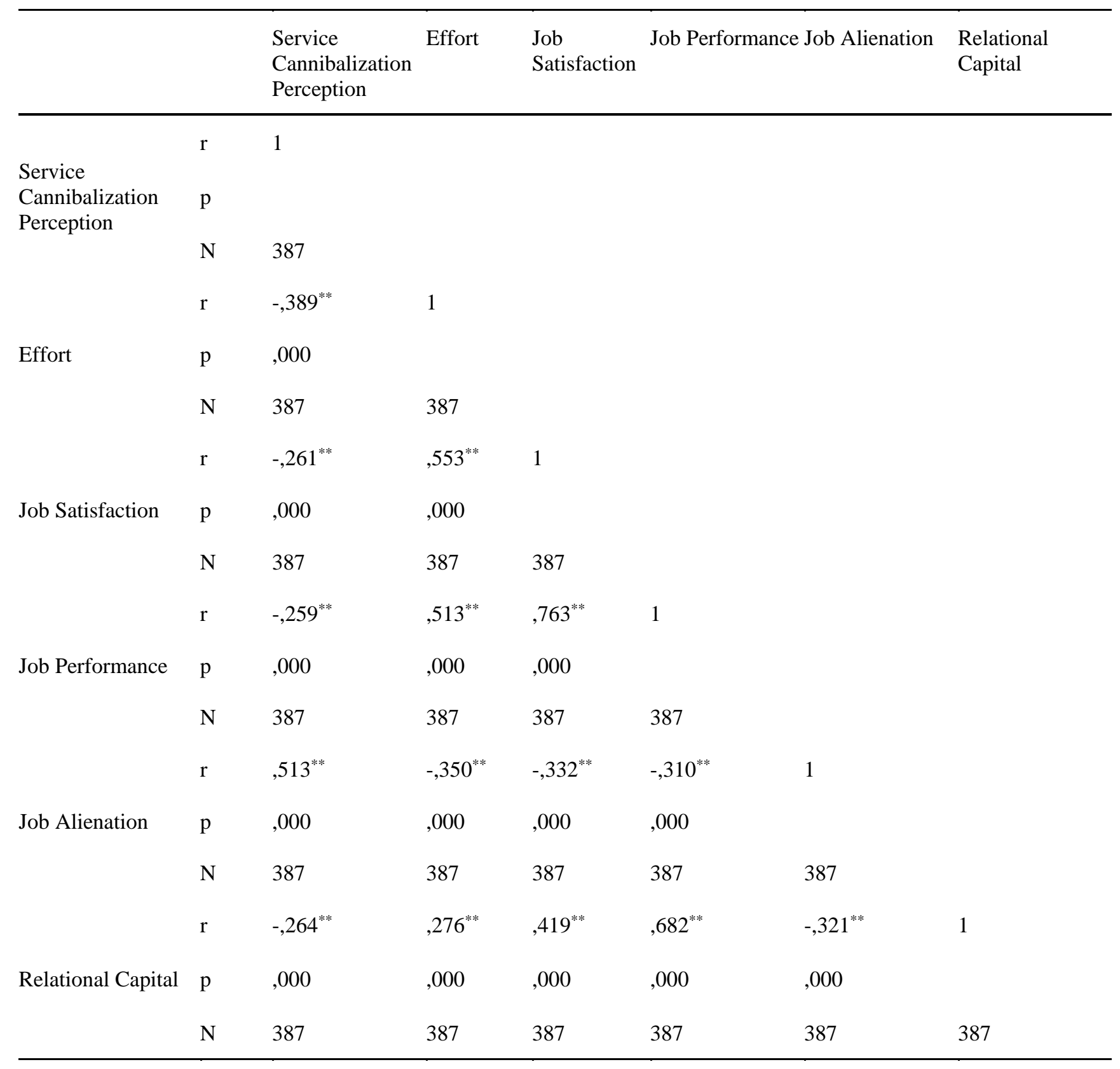

**. Correlation is significant at the 0.01 level (2-tailed). 
Table 5 shows the results of correlation analysis performed to determine the level and direction of service cannibalization perception, effort, job satisfaction, job performance and alienation scale dimensions and relational capital. Correlation relationship between scales was tested by Pearson test. According to this, it was found statistically significant that there was a weak relation with negative direction between the average score of the effort and the service cannibalization of the employees participating in the survey $(r=-0,389, p<0,01)$. Accordingly, $\mathrm{H} 1$ hypothesis was accepted. On the other hand, it was found statistically significant that there was a weak correlation with negative direction between service cannibalization and job satisfaction point average $(r=-0,261, p<0,01)$. Accordingly, $\mathrm{H} 2$ hypothesis was accepted. It was found statistically significant that there was a weak correlation with negative direction between service cannibalization and job performance point average ( $\mathrm{r}=-0,259$, $\mathrm{p}<0,01)$. Accordingly, H3 hypothesis was accepted. Finally, it is statistically significant that there is a positive correlation between the service cannibalization and the alienation point average $(r=0,513$, $\mathrm{p}<0,05)$ and $\mathrm{H} 4$ hypothesis was accepted.

This research seeks to determine whether employees differ in the effect of service cannibalization, whether it is the mediating effect of relational capital between work effort, job satisfaction, job performance and alienation to work, and whether the tool effect differs. In this context, four different hypotheses have been established to achieve the stated objectives. To test the hypotheses, 3-step method of Baron and Kenny is used and to measure the significance of the indirect effect Sobel Test is used. Regression analysis was used to test the method of Baron and Kenny, and for the Sobel test, SOBEL macro, which was developed by Andrew Hayes for the SPSS package program, was used (http://afhayes.com/spss-sas-and-mplus-macros-and-code.html).

Table 6. Relationship Between Perception of Service Cannibalization Perception and Effort Exerted by Relational Capital Instrument Effect

\begin{tabular}{|c|c|c|c|c|c|c|}
\hline \multicolumn{3}{|l|}{ Steps } & $\beta$ & SH & $\mathrm{t}$ & Sig. \\
\hline \multirow{2}{*}{\multicolumn{2}{|c|}{$\begin{array}{l}\text { 1. Step (Service Cannibalization Perception } \\
\mathrm{R}^{2} / \mathrm{F}\end{array}$}} & 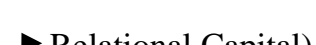 &,- 214 & ,040 & $-5,374$ & ,000 \\
\hline & & & ,070/ & 000 & & \\
\hline \multirow{2}{*}{\multicolumn{3}{|c|}{$\begin{array}{l}\text { 2. Step (Service Cannibalization Perception }>\text { Effort) } \\
\mathrm{R}^{2} / \mathrm{F}\end{array}$}} &,- 268 & ,032 & $-8,277$ & ,000 \\
\hline & & & $.076 /$ & 000 & & \\
\hline \multirow{2}{*}{ 3.Step } & Service Cannibalizat & ion Perception &,- 235 & 041 & 3,890 &, 000 \\
\hline & Relational Capital & & ,159 &, 033 & $-7,100$ &, 000 \\
\hline $\mathrm{R}^{2} / \mathrm{F} /$ & & & \multicolumn{4}{|c|}{$, 183 / 0,000$} \\
\hline
\end{tabular}


When Table 6 is examined, it is seen that the conditions of Baron and Kenny are realized. The first condition was that there was a significant effect between the independent variable (service cannibalization perception) and the mediator variable (relational capital) $(\beta=-0,214, P=0,000)$. The second condition was that there was a significant effect on the dependent variable (effort) of the independent variable (service cannibalization perception). This effect was statistically significant $(\beta=$ ,268 $P=0,000)$. Finally, the mediator (relational capital) is included in the model together with the independent variable (service cannibalization perception) and the dependent variable (effort) is tried to be explained. After this step, if the meaningful effect in the second step is meaningless (full intermediary effect) or the effect level is weak (partial intermediary effect), the tool will give us a clue to the point of being of the effect. When the third step is analysed, the relationship between service cannibalization perception and effort is not meaningless (compared to the second step), but the effect level is reduced $(\beta=-, 235, P=0,000)$. This may result in the partial intermediary effect of the perceived relative capital between the effort made by the service cannibalization perception. However, this is not enough to talk about partial intermediary effect. To reach the result, the significance of the amount of decrease in Beta $(\beta)$ values has to be determined. The level of significance of the decrease in the beta values was determined by using the Sobel Test. According to the result of the Sobel Test, $\mathrm{Z}=3,911$, $\mathrm{P}=0,000$. According to these results, the decrease in the Beta value is significant. After this point, the more relational capital, i.e. the sense of trust, mutual understanding and cooperation with the employees and employers of the employee, the fewer the negative effects that the employee with high of service cannibalization perception can have in his work against the work. In other words, the higher the relational capital, the less the negative impact of service cannibalism perception on effort. In this direction, the H5a hypothesis was accepted.

Table 7. Intermediary Role of Relational Capital on Relationship Between Perception of Service Cannibalization and Job Satisfaction

\begin{tabular}{|c|c|c|c|c|c|c|}
\hline \multicolumn{3}{|l|}{ Steps } & $\beta$ & SH & $t$ & Sig. \\
\hline \multicolumn{2}{|c|}{$\begin{array}{l}\text { 1. Step (Service Cannibalization Perception } \\
\mathrm{R}^{2} / \mathrm{F}\end{array}$} & -Relational Capital) & $\begin{array}{l}-, 214 \\
, 070 / 0,000\end{array}$ &, 040 & $-5,374$ & ,000 \\
\hline \multicolumn{2}{|c|}{$\begin{array}{l}\text { 2. Step (Service Cannibalization Perception } \\
\mathrm{R}^{2} / \mathrm{F}\end{array}$} & Job Performance) & $\begin{array}{l}-, 204 \\
, 068 / 0,000\end{array}$ &, 038 & $-5,314$ & ,000 \\
\hline \multirow[t]{2}{*}{ 3.Step Job Satisfaction } & $\begin{array}{l}\text { Service } \\
\text { Perception }\end{array}$ & Cannibalization &,- 126 & ,037 & $-3,424$ &, 001 \\
\hline & Relational & Capital & ,362 &, 046 & 7,951 &, 000 \\
\hline $\mathrm{R}^{2} / \mathrm{F} /$ & & & $200 / 0,000$ & & & \\
\hline
\end{tabular}


When Table 7 is examined, it is seen that the conditions of Baron and Kenny are realized. The first condition was that there was a significant effect between the intermediary variable (relational capital) and the independent variable (service cannibalization perception) and this was realized $(\beta=$ $0,214, P=0,000$ ). The second condition was that the independent variable (service cannibalization perception) had a meaningful effect on the dependent variable (job satisfaction). This effect was statistically significant $(\beta=-, 204 P=0,000)$. Finally, the mediator variable (relational capital) was included in the model together with the independent variable (service cannibalization perception) and the dependent variable (job satisfaction) was tried to be explained. After this phase, if the meaningful effect in the second step is meaningless (full intermediary effect) or the effect level is weak partial intermediary effect), the tool will give us a clue to the point of being of the effect. When the third step is examined, the relationship between service satisfaction perception and job satisfaction is not meaningless (compared to the second step), but the effect level is reduced $(\beta=-, 126, P=0,000)$. This situation can result in the perceived relational capital between the service cannibalization perception and the job satisfied dimension having the partial intermediary effect. However, this is not enough to talk about partial intermediary effect. To reach the result, the significance of the amount of decrease in Beta $(\beta)$ values has to be determined. The level of significance of the decrease in the beta values was determined using by the Sobel Test. According to the result of the Sobel Test, $\mathrm{Z}=2,872, \mathrm{P}=$ 0,000. According to these results, the decrease in the beta value is significant. After this point, the more relational capital, i.e. the sense of trust, mutual understanding and cooperation with the employees and the employers that the employee is working with, the less negative impacts on the job satisfaction of the employee with high service cannibalization perception. In other words, the high level of the relational capital will reduce the adverse effects of service cannibalization perception on job satisfaction. In this direction, the H5b hypothesis is accepted.

Table 8. Intermediary role of Relational Capital on Relationship Between Perception of Service Cannibalization and Job Performance

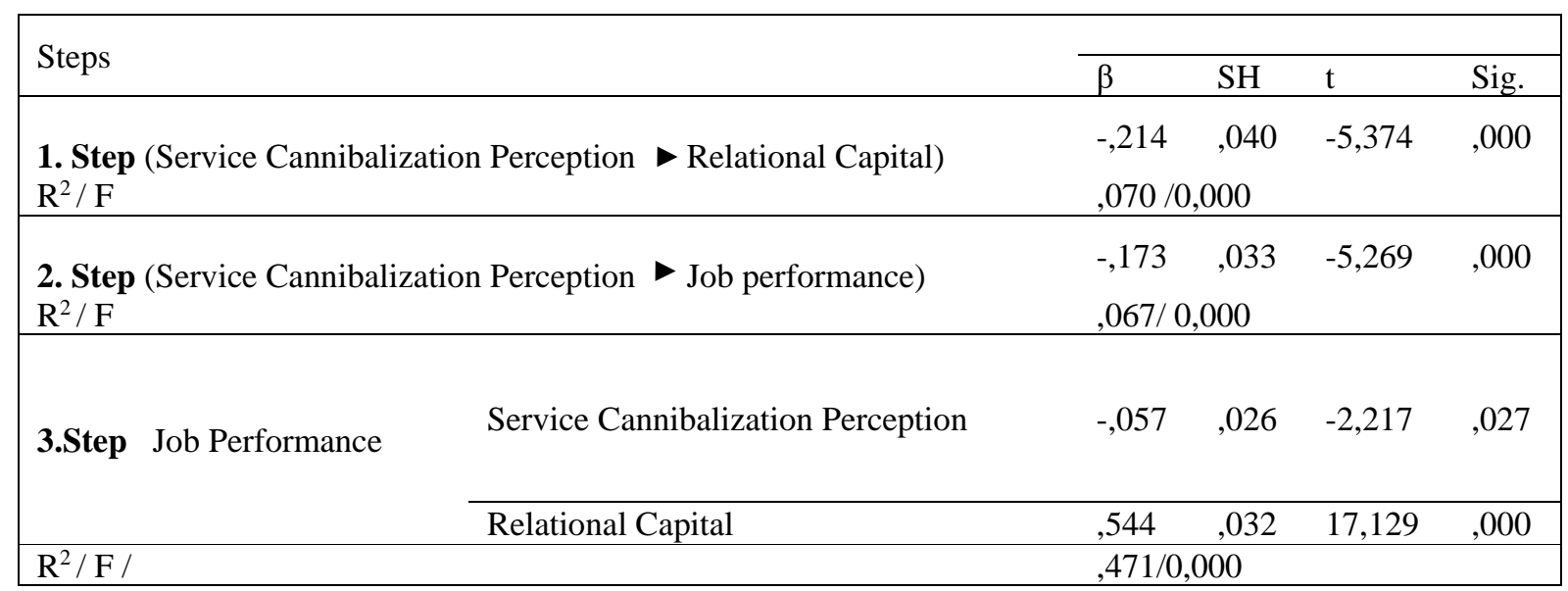


When Table 8 is examined, it is seen that the conditions of Baron and Kenny are realized. The first condition was that there was a significant effect between the intermediary variable (relational capital) and the independent variable (service cannibalization perception) and this was realized $(\beta=$ $0,214, P=0,000$ ). The second condition was that the independent variable (service cannibalization perception) had a meaningful effect on the dependent variable (job performance). This effect was statistically significant $(\beta=-, 173 P=0,000)$. Finally, the mediator variable (relational capital) was included in the model together with the independent variable (service cannibalization perception) and the dependent variable (job performance) was tried to be explained. After this phase, if the meaningful effect in the second step is meaningless (full intermediary effect) or the effect level is weak partial intermediary effect), the tool will give us a clue to the point of being of the effect. When the third step is examined, the relationship between service cannibalization perception and job performance is not meaningless (compared to the second step), but the effect level is reduced $(\beta=-, 057, P=0,000)$. This situation can result in the perceived relational capital between the service cannibalization perception and the Job Performance dimension having the partial intermediary effect. However, this is not enough to talk about partial intermediary effect. To reach the result, the significance of the amount of decrease in Beta $(\beta)$ values must be determined. The level of significance of the decrease in the beta values was determined using by the Sobel Test. According to the result of the Sobel Test, $Z=2,028, P=0,002$. According to these results, the decrease in the beta value is significant. After this point, the more relational capital, i.e. the sense of trust, mutual understanding and cooperation with the employees and the employers that the employee is working with, the less negative impacts on the job performance of the employee with high service cannibalization perception. In other words, the high level of the relational capital will reduce the adverse effects of service cannibalization perception on job performance. In this direction, the H5c hypothesis is accepted.

Table 9. Intermediary role of Relational Capital on Relationship Between Perception of Service

Cannibalization and Job Alienation

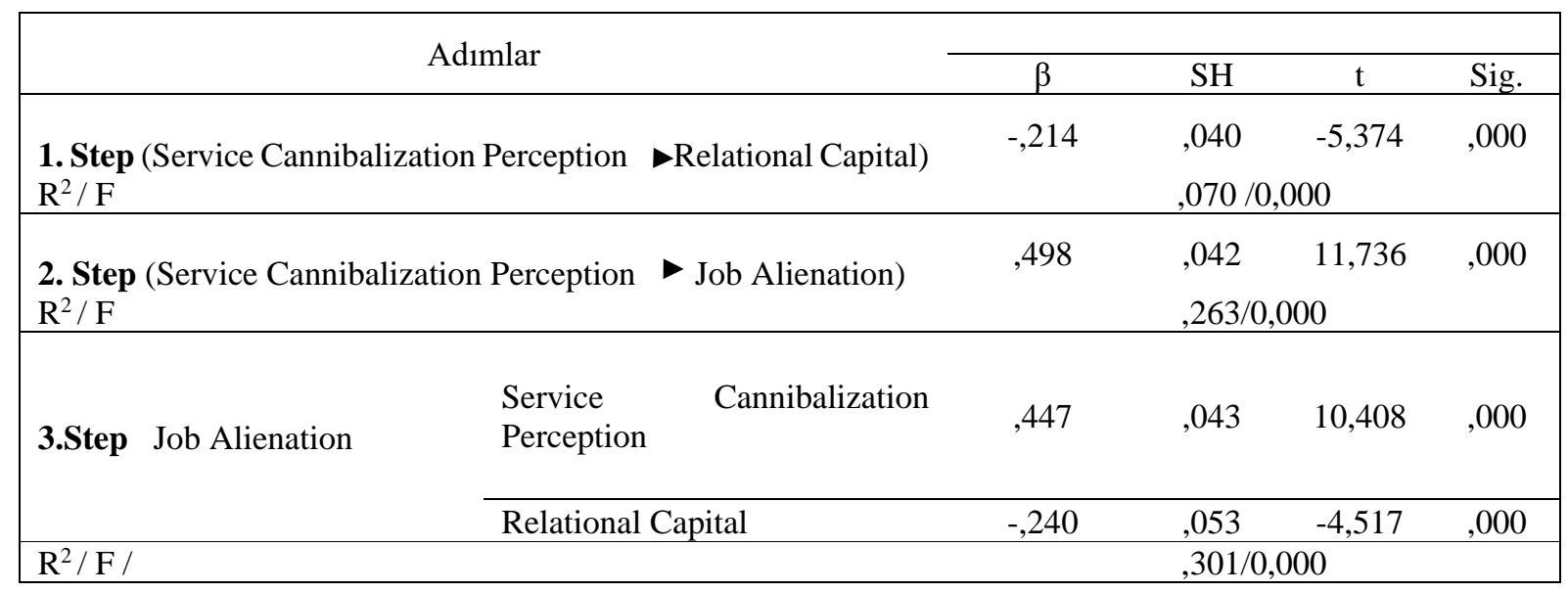


When Table 9 is examined, it is seen that the conditions of Baron and Kenny are realized. The first condition was that there was a significant effect between the intermediary variable (relational capital) and the independent variable (service cannibalization perception) and this was realized $(\beta=$ $0,214, P=0,000$ ). The second condition was that the independent variable (service cannibalization perception) had a meaningful effect on the dependent variable (job alienation). This effect was statistically significant $(\beta=-, 498 P=0,000)$. Finally, the mediator variable (relational capital) was included in the model together with the independent variable (service cannibalization perception) and the dependent variable (job alienation) was tried to be explained. After this phase, if the meaningful effect in the second step is meaningless (full intermediary effect) or the effect level is weak partial intermediary effect), the tool will give us a clue to the point of being of the effect. When the third step is examined, the relationship between service cannibalization perception and job alienation is not meaningless (compared to the second step), but the effect level is reduced $(\beta=-, 447, P=0,000)$. This situation can result in the perceived relational capital between the service cannibalization perception and the alienation dimension having the partial intermediary effect. However, this is not enough to talk about partial intermediary effect. To reach the result, the significance of the amount of decrease in Beta $(\beta)$ values has to be determined. The level of significance of the decrease in the beta values was determined using by the Sobel Test. According to the result of the Sobel Test, $Z=-4,756, P=0,000$. According to these results, the decrease in the beta value is significant. After this point, the more relational capital, i.e. the sense of trust, mutual understanding and cooperation with the employees and the employers that the employee is working with, the more negative impacts on the job alienation of the employee with high service cannibalization perception. In other words, the high level of the relational capital will increase the adverse effects of service cannibalization perception on job alienation. In this direction, the H5d hypothesis is accepted.

\section{CONCLUSION AND DISCUSSION}

ICTs have been able to offer a wide variety of time-saving options to consumers who want to buy tourism products and services, especially with the Internet, online distribution channel and dominating the tourism industry in recent years. However, this situation can cannibalize the sales of sales representatives working at the travel agent and creates ambiguity on sales representatives. The theory of uncertainty reduction, that is, the evaluation of alternatives, plays an effective role in increasing uncertainty, and saying that these alternatives are perceived as cannibalization proves this situation (Planalp and Honeycutt, 1985). The works in the literature also suggests the possibility that sales representatives' cannibalization perceptions will be increased by adding the internet to 
distribution channels (Hagerty, 2005; Porter, 2001). The resulting uncertainty reduces the motivation of sales representatives to reduce the effort they are exerted to their business and to affect their business performance in the negative, which in turn creates fewer satisfying jobs and leads employees to move away from their jobs.

The aim of the research in this context is to determine the perception and possible outcomes of cannibalization created by ICT sales representatives, especially when the internet enters the tourism industry as an alternative distribution channel. Another purpose of the study is to find out how the level of relational capital that employees have, that is, the trust, mutual understanding and cohesiveness of employees with their organizations and employers - the impact of service cannibalization and its possible consequences (effort, job satisfaction, job performance and job alliniation).

According to the results, as a result of the analysis of factor analysis and the reliability of the general scale, all the scale items explained the variance by $70 \%$. As a result, it can be said that this scale applied to sales representatives is reliable and valid (Nunnally and Bernstein, 1994). According to the analysis, it was found out that the average value of the service cannibalization perception of the representatives participating in the study was 3,57 and the average of the relational capital levels was 2.99. In other words, the representatives who participated in the study indicated that the sales of agency were enrolled in the middle level and that the trust, mutual understanding and work association feeling between them and the agency they were working with were low. In Kogut's (1991) study, it is concluded that the high levels of relational capital that employees have are preventing the negative effects on the sales representatives of the internet and the perception that their sales can be cannibalized. It can be argued that the result of the present research overlaps with other theoretical studies on this subject in the literature.

A correlation analysis was conducted to determine the level and direction of service cannibalization perception, effort, job satisfaction, job performance and job alienation scale dimensions and relational capital. According to the results of the analysis, it was seen that the employees' service cannibalization perception of the employees in the survey was negatively correlated with the score average of work effort average, job satisfaction point average, work performance point average. However, it is statistically significant that there is a mean positive relationship with the alienation point average. The results of the current research are like those of the literature (Di Mauro and Musumeci, 2011; Rothmann and Cooper, 2008).

Finally, a regression analysis was conducted with the aim of determining whether the employees were affected by the service cannibalization and the possible consequences of the 
relationship between effort, job satisfaction, job performance and alienation, and whether the tool effect was different. According to the analysis results, the higher the relational capital level, that is, the higher the sense of trust, mutual understanding and co-operation with employees and employers, the lower the negative impact on employee effort, job satisfaction and job performance with higher service cannibalization perception. That is, the high level of the relational capital reduces the negative effects of the service cannibalization perception on the consumed effort, job satisfaction and work performance.

In addition, the result that employees with high relational capital are increasing the adverse effects of high service cannibalization perceptions on work alienation has also been determined. The results of the research are in line with other research results in the literature. (Dwyer et al.,1987; Morgan and Hunt, 1994). Within the scope of these results reached in the current research, some suggestions can be made for the travel industry in tourism. Johnson and Bharadwaj (2005) argue that businesses should provide motivational training for employees in a multichannel distribution environment and should strive to improve their skills by providing their employees with the technological elements necessary to reach the strategy of the operator. Thus, by improving the skills of sales representatives and adapting them to changing conditions and today's dynamic environments, businesses will be able to meet the needs of their consumers, while at the same time ensuring the survival of the business by breaking the atmosphere of insecurity against work (Marimuthu et al., 2009).

Travel agencies that accept to use these channels as alternative options because of the widespread use of ICTs in the tourism industry and internet distribution channels should develop effective and encouraging systems in order to reduce the negative feelings of sales representatives who think that they perceive this as competition and the internet cannibalize their sales. One way of doing this is to teach sales representatives to use the internet in ways that make it useful for their own sales. For example, in the case of sales through internet channels, all services and services provided must be satisfactory for the consumer to repeatedly choose the same agency, because many other agencies on the internet are only at a key distance. For this, the agency must be trained to provide all the services that facilitate the customer's business, such as the sales representative's telephone support. While increasing their associate capital with their agents and this will reduce the negative effects that will create the feeling of cannibalization of their sales, and they will feel that their role is safe at work.

Goldmanis et al. (2010) suggested that the potential impact of the use of internet distribution channels influence small-scale travel agencies in the market they serve more than the influence on major agencies. Because the agency groups and species will affect the outcome of this work, the 
agencies will change the results of studying participation in the work as a variant in future work. Future work may also examine how online training channels can affect service cannibalization perceptions in sales representatives. 


\section{REFERENCES}

Agarwal, S. (1993). Influence of formalization on role stress, organizational commitment, and work alienation of salespersons: a cross-cultural comparative study. Journal of International Business Studies, 24(4), 715-739.

Akerlof, George A., ve Janet L. Yellen (1990). The Fair wage-effort hypothesis and unemployment. Quarterly Journal of Economics, 105 (2), 255-283.

Alba, J., Lynch, J., Weitz, B., Janiszewski, C., Lutz, R., Sawyer, A., ve diğerleri. (1997). Interactive home shopping: consumer, retailer, and manufacturer incentives to participate in electronic marketplaces. Journal of Marketing, 61(3), 38-53.

Allen, B.H. ve La Follette, W.R. (1977). Perceived organizational structure and alienation among management trainees. The Academy of Management Journal, Vol. 20 No. 2, pp. 334-41.

Amyx, Douglas A., Shahid N. Bhuian, Dheeraj Sharma ve Katherine E. Loveland (2008). Salesperson corporate ethical values (SCEV) Scale: Development and assessment among salespeople. Journal of Personal Selling \& Sales Management, 28, 4 (Fall), 387-402.

Ansari, A., Mela, C. F., ve Neslin, S. A. (2008). Customer channel migration. Journal of Marketing Research, 45(1), 6076.

Ashford, Susan J., Cynthia Lee, ve Philip Bobko (1989). Content, causes, and consequences of job insecurity: A Theorybased measure and substantive test. Academy of Management Journal, 32 (4), 803-829.

Berné, C., García-González, M., García-übeda, M. E., ve Múgica, J. M. (2015). The effect of ICT on relationship enhancement and performance in tourism channels. Tourism Management, 48(June), 188-198.

Bennett, M., ve Buhalis, D. (2003). The future for internet travel distribution: the travel agent perspective. Insights, 25-30.

Berne, C., Garcia-Gonzalez, M., ve Múgica, J. (2012). How ICT shifts the power balance of tourism distribution channels. Tourism Management, 33(1), 205-214.

Berger, C.R. (1986). Uncertain outcome values in predicted relationships: uncertainty reduction theory then and now. Human Communication Research, Vol. 13 No. 1, pp. 34-8.

Berger, C.R. (1979). Beyond initial interaction: uncertainty, understanding, and the development of interpersonal relationships. In Giles, H. and St Clair, R. (Eds), Language and Social Psychology, Blackwell, Oxford, pp. 12244.

Blauner, R. (1964). Alienation and Freedom, University of Chicago Press, Chicago, IL.

Boonzaier, Billy, Bernhard Ficker, ve Braam Rust (2001). A review of research on the job characteristics model and the attendant job diagnostic survey. South African Journal of Business Management, 32 (1), 11-35.

Brown, Steven P., ve Robert A. Peterson (1994). The effect of effort on sales performance and job satisfaction. Journal of Marketing, 58 (April), 70-80.

Buhalis, D., ve Law, R. (2008). Progress in information technology and tourism management: 20 years on and 10 years after the internet - the state of e-tourism research. Tourism Management, 29(4), 609-623.

Buhalis, D., ve Laws, E. (2001). Tourism distribution channels: Practices, issues, and transformations. London: Continuum.

Buhalis, D., ve Michopoulou, E. (2013). Information provision for challenging markets: The case of the accessibility requiring market in the context of tourism. Information \& Management, 50(5), 229-239.

Calabrese, F.A. (2005), "The early pathways: theory to practice - a continuum", in Stankosky, M. (Ed.), Creating the Discipline of Knowledge Management, Elsevier, New York, NY, pp. 15-20.

Capizzi, M. T and Ferguson, R. (2005), "Loyalty trends for the twenty-first century", Journal of Consumer Marking, Vol. 22 No. 2, pp. 72-80.

Cai, G., Zhang, Z. G., ve Zhang, M. (2009). Game theoretical perspectives on dual channel supply channel competition with price discounts and pricing schemes. International Journal of Production Economics, 117(1), 80-96.

Cheung, C. K. (2005). Rational or demoralized responses to work restructuring in Hong Kong? Human Relations, 58(2), 223-247.

Coughlan, A. T., Anderson, E., Stern, L. W., ve El-Ansary, A. I. (2001). Marketing channels. Upper Saddle River, NJ: Prentice-Hall. 
D'Aveni, Richard A. (1989). The aftermath of organizational decline: A longitudinal study. Academy of Management Journal, 32 (3), 577-606.

Davy, Jeanette A., Angelo J. Kinicki, ve Christine L. Scheck (1997). A Test of job security’s direct and mediated effects on withdrawal cognitions. Journal of Organizational Behavior, 18 (4), 323-349.

Dekker, Sidney W.A., ve Wilmar B. Schaufeli (1995). The Effects of job insecurity on psychological health and withdrawal: A longitudinal study. Australian Psychologist, 30, 57-63.

Di Mauro, C., ve Musumeci, R. (2011). Linking risk aversion and type of employment. Journal of Socio-Economics, 40(5), 490-495.

Di Pietro, R. B., ve Pizam, A. (2008). Employee alienation in the quick service restaurant industry. Journal Hospitality and Tourism Research, 32(1), 22e39.

Byrne, B. M., Shavelson, R. J., \& Muthén, B. (1989). Testing for the equivalence of factor covariance and mean structures: The issue of partial measurement invariance. Psychological Bulletin, 105, 456-466.

Dwyer, R.F. ve Oh, S. (1987). Output sector munificence effects on the internal political economy of marketing channels. Journal of Marketing Research, Vol. 24 No. 4, pp. 347-58.

Dwyer, Sean, John Hill, ve Warren Martin (2000). An Empirical investigation of critical success factors in the personal selling process for homogenous goods. Journal of Personal Selling \& Sales Management, 20, 3 (Summer), 151159.

Frazier, Gary L. (1999). Organizing and managing channels of distribution. Journal of the Academy of Marketing Science, 27 (2), 226-240.

Geyskens, I., Gielens, K., ve Dekimpe, M. G. (2002). The market valuation of internet channel additions. Journal of Marketing, 66(2), 102-120.

Ghosh, Shikhar (1998). Making business sense of the Internet. Harvard Business Review, 76 (2), $126-135$.

Gouldner, Alvin W. (1960). The norm of reciprocity: A preliminary statement. American Sociological Review, 25 (2), 161178.

Goldmanis, M., Hortaçsu, A., Syverson, C., ve Emre, O. (2010). E-commerce and the market structure of retail industries. The Economic Journal, 120(545), 651-68.

Granovetter, Mark S. (1973). The strength of weak ties. American Journal of Sociology, 78 (6), 1360-1380.

Greenhalgh, Leonard, ve Zehava Rosenblatt (1984). Job insecurity: Toward conceptual clarity. Academy of Management Review, 9 (July), 438-488.

Gulati, R., Bristow, D., ve Dou, W. (2002). A three-tier model representing the impact of internet use and other environmental and relationship-specific factors on a sales agent's fear of disintermediation due to the internet medium. Journal of Marketing Channels, 9(3/4), 49-86.

Hagerty, J.R. (2005). Crowded house: discount real-estate brokers spark a war over commission. Wall Street Journal, No. 245, p. 1 .

Hall, Douglas T., ve Edward E. Lawler (1970). Job characteristics and job pressures and the organizational integration of professionals. Administrative Science Quarterly, 15, 271-281.

Harrow, R. (2005). No Place to Hide, Simon\& Schuster, New York, NY.

Hellgren, Johnny, Magnus Sverke, ve Kerstin Isaksson (1999). A Two-Dimensional approach to job insecurity: Consequences for employee attitudes and well-being. European Journal of Work \& Organizational Psychology, 8 (2), 179-195.

Hjalager, A. M. (2010). Progress in tourism management: A review of innovation research in tourism. Tourism Management, 31(1), 1-12.

Hirschfeld, R. R., Feild, H. S., ve Bedeian, A. G. (2000). Work alienation as an individual-difference construct for predicting workplace adjustment: a test in two samples. Journal of Applied Social Psychology, 30(9), 1880-1902.

Hinrichs, John R. (1968). Replication study of job satisfaction dimensions. Personal Psychology, 21 (4), $479-503$.

Homburg, C., ve Stock, R. M. (2004). The link between salespeople's job satisfaction and customer orientation in a business-to-business context: a dyadic analysis. Journal of the Academy of Marketing Science, 32(2), 144-158.

Hudson, S. (2008). Tourism and hospitality marketing. A global perspective. London: Sage Publications. 
Hunt, Shelby D., Lawrence B. Chonko, ve Van R. Wood (1985). Organizational commitment and marketing. Journal of Marketing, 49 (1), 12-26.

Jakkilinki, R., Georgievski, M. and Sharda, N. (2007), "Connecting destinations with an ontology-based e-tourism planner", in Information and communication technologies in tourism 2007 proceedings of the international conference in Ljubljana, Slovenia, 2007, Springer-Verlag, Vienna, pp. 12-32.

Johnson, D. S., ve Bharadwaj, S. (2005). Digitization of selling activity and sales force performance: an empirical investigation. Academy of Marketing Science Journal, 33(1), 3-18.

Kale, Prashant, Harbir Singh, ve Howard Perlmutter (2000). Learning and protection of proprietary assets in strategic alliances: Building relational capital. Strategic Management Journal, 21 (3), 217-238.

Kline, P. (1994). An Easy Guide To Factor Analysis:. New York: Routledge.

Kollmann, T., Kuckertz, A., ve Kayser, I. (2012). Cannibalization or synergy? Consumers' channel selection in onlineoffline multichannel systems. Journal of Retailing and Consumer Services, 19(2), 186-194

Kracht, J., ve Wang, Y. (2010). Examining the tourism distribution channel: evolution and transformation. International Journal of Contemporary Hospitality Management, 22(5), 736-757.

Locke, E. A. (1979). What is job satisfaction? Organizational behaviour and human performance. Journal of Applied Psychology, 4(4), 309-336.

Locke, Edwin A. (1976). The nature and causes of job satisfaction. In handbook of industrial and organizational psychology, Marvin D. Dunnette, ed., Chicago: Rand McNally, pp. 1297-1349.

Mackenzie, Herbert F. (1996). Manage your offering or manage your relationship?. Journal of Business \& Industrial Marketing, 11 (6), 20-37.

Marimuthu, M., Arokiasamy, L., ve Ismail, M. (2009). Human capital development and its impact on firm performance: evidence from developmental economics. The Journal of International Social Research, 2(8), 265-272.

Moch, M.K. (1980). Racial differences in job satisfaction: testing four common explanations. Journal of Applied Psychology, Vol. 65 No. 3, pp. 299-306.

Morgan, R.M. ve Hunt, S.D. (1994). The commitment-trust theory of relationship marketing. Journal of Marketing, Vol. 58 No. 3, pp. 20-38.

Moizer, P. (2003), "How published academic research can inform policy decisions: the case of mandatory rotation of audit appointments", working paper, Leeds University Business School, University of Leeds, Leeds, 28 March.

Narayandas, D., Caravella, M., ve Deighton, J. (2002). The impact of internet exchanges on business-to-business distribution. Journal of the Academy of Marketing Science, 30(4), 500-505.

Netemeyer, R. G., Johnston, M. W., ve Burton, S. (1990). Analysis of role conflict and role ambiguity in a structural equations framework. Journal of Applied Psychology, 75(2), 148-157.

Nunnally, J., ve Bernstein, I.(1994) Psychometric Theory. New York: McGraw-Hill.

Planalp, S., ve Honeycutt, J. M. (1985). Events that increase uncertainty in personal relationships. Human Communication Research, 11(4), 593-604.

Pearce, D. G., ve Tan, R. (2006). The distribution mix for tourism attractions in Rotorua, New Zealand. Journal of Travel Research, 44(3), 250-258.

Pearce, D. G. (2009). Channel design for effective tourism distribution strategies. Journal of Travel \& Tourism Marketing, 26(5/6), 507-521.

Porter, M. E. (2001). Strategy and Internet. Harvard Business Review, 79(3), 62-79.

Roger-Monzó, V., Martí-Sánchez, M., ve Guijarro-García, M. (2015). Using online consumer loyalty to gain competitive advantage in travel agencies. Journal of Business Research.

Rogers, Ronald W. (1975). A Protection motivation theory of fear appeals and attitude change. Journal of Psychology, 91 (September), 93-114.

Rosenblatt, Zehava, ve Ayalla Ruvio (1996) .A test of a multidimensional model of job insecurity: The case of Israeli teachers. Journal of Organizational Behavior, 17 (Special Issue), 587-605.

Rothmann, S., ve Cooper, C. L. (2008). Organizational and work psychology. London: Hodder Education. 
Rousseau, Denise M. (1989). Psychological and implied contracts in organizations. Employee Responsibilities and Rights Journal, 2 (2), 121-139.

Sallee, Amy, ve Karen Flaherty (2003). Enhancing salesperson trust: An examination of managerial values, empowerment, and the moderating influence of SBU strategy. Journal of Personal Selling \& Sales Management, 23, 4 (Fall), 299-310.

Seabright, Mark A., Daniel A. Levinthal, ve Mark Fichman (1992). Role of individual attachments in the dissolution of interorganizational relationships. Academy of Management Journal, 35 (1), 122-160.

Shannon, C.E. ve Weaver, W. (1949). The Mathematical Theory of Communication, University of Illinois Press, Urbana, IL.

Sharma, D., ve Gassenheimer, J. B. (2009). Internet channel and perceived cannibalization. Scale development and validation in a personal selling context. European Journal of Marketing, 43(7/8), 1076-1091.

Sharma, D., Gassenheimer, J. B., ve Alford, B. L. (2010). Internet channel and cannibalization: an empirical assessment of sales agents' perspective. Journal of Personal Selling and Sales Management, 30(3), 209-221.

Shepard, J. (1971). Automation and Alienation, MIT Press, Cambridge, MA.

Smith, A. (2008), "Money for old rope", Daily News, 21 January, pp. 1, 3-4.

Şimşek, Ö. F. (2007). Yapısal Eşitlik Modellemesine Giriş Temel İlkeler ve LISREL Uygulamaları. Ankara: Ekinox.

Standing, C., Tang-Taye, J. P., ve Boyer, M. (2014). The impact of the Internet in travel and tourism: A research review 2001-2010. Journal of Travel and Tourism Marketing, 31(1), 82-113.

Staw, Barry M., Lance E. Sandelands, ve Jane E. Dutton (1981). Threat-rigidity effects in organizational behavior: A multilevel analysis. Administrative Science Quarterly, 26 (4), 501-524.

Sigala, M., ve Chalkiti, K. (2014). Investigating the exploitation of Web 2.0 for knowledge management in the Greek tourism industry: An utilization importance analysis. Computers in Human Behavior, 30(1), 800-812.

Thibaut, John W., ve Harold H. Kelley (1959).The social psychology of groups, New York: John Wiley \& Sons.

Vroom, Victor H. (1964), Work and Motivation, New York: Wiley.

Walsh, James P. (1988). Selectivity and selective perception: An investigation of managers' belief structures and information processing. Academy of Management Journal, 31 (4), 873-896.

Wang, Y., ve Qualls, W. (2007). Towards a theoretical model of technology adoption in hospitality organizations. International Journal of Hospitality Management, 26(3), 560-573.

Zaheer, Akbar, Bill McEvily, ve Vincenzo Perrone (1998). Does trust matter? Exploring the effects of interorganizational and interpersonal trust on performance. Organization Science, 9 (2), 141-159. 